\title{
Consideration of Custom ('Urf) by the Izalah Organization in Gombe, Nigeria: A Critical Examination $^{i}$
}

\author{
Aishatu Abubakar Kumo, ${ }^{1}$ Sayed Sikandar Shah, ${ }^{2}$ Luqman Zakariyah ${ }^{3}$
}

\begin{abstract}
'Urf in the Sharī'ah serves as an essential tool for dealing with mu'āmalāt aspects of Muslim life. The 'urf rulings stipulated by the scholars determine its acceptability or otherwise. A certain 'urf serves as a legal principle to conduct a transaction in social interaction. However, Jamō'atu Izalatil bid'a wa Iq $\bar{\alpha} m a t i s$ Sunnah (The Society for the Removal of Innovation and Establishment of the Sunnah) uses the term bid'ah indiscriminately to include some customary practices in mu' $\bar{\alpha}$ malāt. This leads to a different perception of how people understand the word and its application, which gives a different dimension of interpretation on the Sharī'ah allowance of 'urf usage. Thus, depicting 'urf as bid'ah complicates the ability to verify the crux of bid'ah in matters pertaining to 'ib̄̄dah and mu'āmalāt in their respective domains. The results of the qualitative research conducted in Gombe metropolis show the people's understanding and utilization of the words to be synonymous. This is a result of the Izalah organization's application of the two words (bid'ah and 'urf) in dealing with mu'āmalāt as well as 'ib̄adah. Muslims misunderstood the utilization of these terms and therefore misapply some practical Sunnah in marriage celebrations, for example, as bid'ah. Therefore, there is need for the organization to educate Muslims on the validity of customary practices that do not contravene the teachings of Islam.
\end{abstract}

Keywords: 'Urf, Bid'ah, Rulings, Interaction, Izalah

\section{مراعاة آلية "العرف" لدى جماعة الإزالة في ولاية غونبي، نيجيريا: دراسة نقدية} ملخص البحث

العرف في الشريعة الإسلامية بمثابة أداة أساسية في التعامل مع جانب المعاملات في حياة المسلم. وأحكام العرف كما نص عليها العلماء تقرّر مدى قبوله ورفضه. وهناك بعض الأعراف بمثابة أداة لإجراء المعاملات بين أفراد المجتمع. واستخدام -"جماعة إزالة البدعة وإقامة السنة" النيجيرية- هذا المصطلح في جوانب معينة، قد مهد لتصور آخر في كيفية فهم الناس للمصطلح وتنفيذه. وتصور "العرف" كأنه مقابل للبدعة يجعل استخدامه معقدا في معرفة ما دخل في إطار البدعة وما لم يدخل فيه من المسائل المتعلقة بالعبادات والمعاملات. وقد أظهرت نتيجة البحث النوعي الذي تم إجراؤه في عاصمة ولاية غومبي، نيجيريا، فهم بعض الناس لمذا المصطلح واستخدامهم للكلمتين مثل المترادفات. وهذا ما كان إلا نتيجة لاستخدام الجماعة المذكورة لمذين المصطلحين في تعاملهم مع المسائل المتعلقة بالعبادات والمعاملات. وقد ساء فهم المسلمين لاستخدام المصطلحين. ومن ثم أساؤا استخدام بعض السنن العملية في احتفالات الزواج واعتبروها كبدعة. ولذا هناك حاجة لمذه المؤسسة أن تعلم المسلمين حول صلاحية تلك التقاليد العرفية التي لا تعارض تعليمات الإسلام. الكلمات المفتاحية: العرف، آلية، الأحكام، التفاعل الاجتماعي، جماعة إزالة

${ }^{1}$ Doctoral Candidate, Institute of Islamic Thought and Civilization \& Malay World, International Islamic University Malaysia, (IIUM); A lecturer, Department of Religious Studies, Faculty of Arts and Social Sciences, Gombe State University, Gombe, Nigeria. jauroji1988@gmail.com

${ }^{2}$ Professor, Department of Fiqh \& Usul al-Fiqh, International Islamic University Malaysia, (IIUM). sayedsikandar@iium.edu.my

${ }^{3}$ Assoc. Professor, Department of Fiqh \& Usul al-Fiqh, International Islamic University Malaysia, (IIUM). luqzak@iium.edu.my 



\section{Contents}

Introduction

103

Methodology

103

The concept of 'Urf or 'Ādah (Customs) in Islamic Jurisprudence

'Urf and Bid'ah in the Sharī'ah

Perception of Izalah Movement on 'Urf

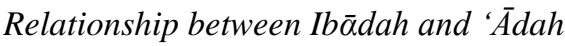

Custom as the basis of judgment." (Al- 'Ādah

Muhakkamah)

Marriage Customs in Islam

Hausa/Fulani People's Perception on Family Customs

Conclusion

References

Endnotes

\section{Introduction}

Jamō'atu Izalatil bid'a wa Iq $\bar{\alpha} m a t i s$ Sunnah (The

Society for the Removal of Innovation and

Establishment of the Sunnah), popularly known

as Izalah, is a non-governmental organization in

Nigeria. The activities of the organization revolve around guiding Muslims to abide by the Sunnah of the Prophet (S.A.W.) and shunning bid'ah. The main objectives of the movement are to preach, guide, and uphold true doctrines, teachings, and practices of Islam as stipulated in the Qur'ān and traditions of the Prophet (S.A.W.). At the same time, they are out to eliminate all forms of religious ignorance, heretic Șüfi innovations and new practices introduced into Islam.

Every society has its customary practices some of which are in line with the dictates of the Sharī'ah, and some of which contradict the Sharī'ah. As such, in the Izalah organization's effort to rectify some of the assumed heretical doctrines of Sufism, it uses the word bid'ah to

refer to any act contradictory to the teachings of the Prophet (S.A.W.). This helps in forming a method of identifying the correct teachings of Islam from incorrect practices by some $S u \overline{f i}$ scholars. Due to the frequent usage of the word by this organization in the procedures of explaining and clarifying intricate issues, some of the 'urf in mu'ämalah has also become bid'ah. As a result, the majority of the Muslims in Gombe consider some of the accepted customs of marriage in Islam as bid' $a h$.

\section{Methodology}

The method of data collection adopted in this paper is qualitative. Ten persons were interviewed (Bryman, 2015; Creswell, 2013), from among the Izalah organization's officials, Muslim affiliates of the organization, and nonaffiliates. The results of the interview displayed the adoption of the word bid'ah in matters of ти' $\bar{\alpha}$ malah, particularly in marriage where it rarely fits. The reason may be connected to the usage of the word by the organization especially at its inception without proper explanation. The interviews were transcribed, and a content analysis method was applied to triangulate with other literatures (Bowen, 2009). Thus, an inductive method was utilized. The analysis revealed the widespread utilization of the concept in all situations without delineation.

\section{The concept of 'Urf or 'Adah (Customs) in}

\section{Islamic Jurisprudence}

'Urf is a noun derived from the Arabic root 'arafa (to know), which literally means, 'which is known' (al-Fayrūzabadī, 1996: 1080; Ibn 
Manzūr, 1990:236; Al-Ẓāwī, 1971:198). In its primary sense, it refers to something known as opposed to unknown, familiar and customary, as opposed to unfamiliar and strange. Technically, 'urf can be defined as 'recurring practices that are acceptable to people of sound nature' (al-Burnu, 2002). They are matters on which communities of people agree on in the course of their daily life. It comprises of their actions, speeches and legacies (Zaydan, 1985). This means a common action which is repeatedly performed by individuals and communities. It is something that is practiced by the community or a group of people to the extent of being accepted as binding upon them. 'Urf normally denotes the collective practice of a large number of people. It does not refer to the personal habits of an individual or a minority group (Kamali, 2003).

Going by the above definitions, 'urf could therefore be termed as societal values, philosophies, concords, and principles. It could also be interpreted as the traditions of people of sound minds. For 'urf to serve legal purposes, it must be logical as well as represent the refined aspect of customs, at least according to some classical scholars (Salisu, 2013).

The majority of the scholars make use of 'urf and 'ādah largely synonymously. It signifies a collective practice of a large quantity of people. However, 'a dah, is derived from the Arabic letters 'ayn, waw, and dāl, which means, among other things, 'return'. It also signifies custom, manner, and habit to which people frequently return to from time to time (Al-Isfahōni, n.d). 'A $d a h$ is defined as "practices that have penetrated deep among people by recurrence and is acceptable to people of sound nature" (alZarqa,1983:132), or a "repeated matter which has no connection with reason". 'Urf, is said to be synonymous to 'âdah because they resemble each other in definition and concept (Al-Burnu, 2002). According to al-Zurq $\bar{\alpha}$ 's definition, 'urf can be regarded as lesser in scope than 'addah as it is the custom of a group of people (al-Zurqā, 1983). However, 'ādah could refer to either an individual's custom, such as a woman's custom to menstruate, or a group's custom, such as terms used among a large number of people especially in transactions or skills. In other words, all 'urf is 'Ádah but not all 'Ádah is 'Urf (Zakariyah, 2012).

As discussed above, the use of ' $\bar{a} d a h$ and 'urf is controversial. However, one can categorically say that these terms are often used interchangeably (Kamali, 2003). Ibn 'Ābidīn (d. 1252 A. H.) remarks that habit is derived from frequency and recurrence, because it happens frequently and in succession (Ibn Abidin, 2000). Hence, 'A dah and 'urf implies the same meaning despite their conceptual dissimilarities. It is also essential to note that, for 'urf to be acknowledged and functional in Islam, it must not contradict any injunction of the Shari ${ }^{\complement} a h$.

Finally, from the various definitions on 'urf and 'àdah, it can be inferred that for any social practice to be recognized as such, it must relate to a group of people, and must be reasonable, and should not contradict the Sharīicah. Therefore, Muslims of sound mind should not accept any costmary practice that is prejudicial to the people or encourages corruption (fasād). 


\section{Urf and Bid'ah in the Sharī $a h$}

Since cultures or customs comprise of several actions of a human of a particular group, through a certain period of time (Quirk, Randolph et al, 1983), it is accepted as legal principles of the Sharī'ah with certain rules and regulations. This definition entails the philosophy of a group of people or a community, encompassing of how they conduct their live, in terms of belief system, treasured (arts), and social values; marital and matrimonial life, food, cloth, shelter and so on (Shaboyede, 1992). Thus, there is a need to check the compatibility of the customs with the principles governing them.

In Islam, the Sharīach regulations of 'Ib $\bar{\alpha} d a h$ (religious matters) are stipulated by the Qur'ān and Sunnah of the Prophet (S.A.W.). While 'Ādah or 'Urf (in mu'amalāt) play a significant role in regulating some family matters and transactions, the latter are regulated within the scope of human reasoning, which can be discovered and differentiated between good and evil through human experience, while the former are by stipulated injunctions from the Qur'ān and Sunnah.

In $M u$ 'āmalōt, the criterion for measuring customs and cultures are based on the general principle of "whatever is not prohibited is in fact permissible" or "everything is permissible except what is prohibited by a clear and decisive (qat'î) text of the Qur'ān or Sunnah" (Zakariyah, 2012: 86). In other words, before a particular custom is prohibited, a clear text must be provided. In socio-cultural affairs, evidence from the Qur'ānic or hadìth text is not required for permission (as long as it does not contradict the Qur'ān and hadīth). In fact, it is only required before a customary practice in relation to $M u$ 'a mal $\bar{\alpha} t$ is prohibited. Besides, to discard a sound custom and its usage brings about unnecessary difficulty and un-warranted harm to the people. Going by the principle of Islamic jurisprudence, which emphasizes and advises that: "cultural usage is second to nature", it implies here that it is a difficult thing for people to go against their instinctive natures; the established customs are part and parcel of their life. Besides, Islam does not bring hardship to its adherents.

Apart from this, the actions and speech of people are of two types: acts of worship established by their religion and the customary acts which are required by their daily activities and at times by instinct. In matters of worship, the general principle according to some of the scholars is that everything is prohibited except what is approved by the Qur'ān or the Sunnah (Majallah, article 5; Keller, 1995). That is, textual evidence is required for any act of worship ('ib̄̄dah) or religious belief ('aqidah) to be established as permissible. Matters related to this are religious emblems, or anything uniquely identified with a certain religious group, such as a belief, act of worship, dress, groom, custom, celebrations, festivals, and others. These are either discouraged or prohibited, unless with textual proof for its permissibility. This can be backed by referring to the sayings of the Prophet (S.A.W.): "He is not one of us who imitates a people other than us. Do not imitate the Jews and Christians" (Al-Tirmidhī, no.:120712). Another hadìth states that: "Whoever imitates a people is one of them" (Musnad Ahmad, no. 13). Several 
examples can be found in the ways Muslims conduct their marriage ceremony and matrimonial life similar to the people of the book, without knowledge of the idea behind the act by the latter. In the Shari ${ }^{\top} a h$, the acts of 'ib $\bar{\alpha} d a h$ are those prescribed by Allah and endorsed by the Prophet's (S.A.W.) actions or approvals. Except through these two sources, no other sources can be acknowledged as having any weight with regards to 'ib $\bar{\alpha} d a h$.

For customary activities of the people, the principle is freedom of action. Restrictions take place only where the Sharīah has made prohibitions. To refute any action contrary to that, Allah says in the Qur'ān: 'He it is Who created for you all that is on earth...' (A1Baqarah: 29; Al-'Arāf: 32). In another place, Allah states: Do you see what Allah has sent down to you for sustenance? Yet you have made some part of it halal and some part haram?" (AlYūnus: 59). The stand of the Sharî $a h$ is that people are free to buy, sell, lease, just as they are free to eat and to drink what they like as long as it does not fall into the categories of prohibitions. The criteria for measuring customs and cultures is based on the general principle of "whatever is not prohibited is in fact permissible" or "everything is permissible except what is prohibited by a clear and decisive (qat'î) text of the Qur'ān or Sunnah" (Majallah, article 5). The strongest ruling that most scholars of Islam are in agreement with is that things in principle are permissible. Even though there may be disapproved acts, they are free as long as the Sharī'ah does not prohibit them. Thus, the original principle of permissibility remains (Al-
Qardawi, 2003). Therefore, a local custom or tradition is allowed, if it does not contradict the Sharīah.

\section{Perception of Izalah Movement on 'Urf}

In order to rectify some problems and provide lasting solutions to any contradictory customs, some Muslim scholars considered reviving family life of Muslims in northern Nigeria. The task of preaching and enlightenment campaigns against practices that contradicted Islamic injunctions arose from some scholars most notably Abubakar Mahmud Gumi (d.1990). Accordingly, the explanations given by this scholar as utilized by one of his students, Ismō'îl Idrīs, led to the emergence of the Islamic organization popularly known as Izalah $^{2}$ (Gumi \& Tsiga, 1992; Modibbo, 2012; Ousman, 2003; Thurston, 2009; Loimeier, 1997).

The major preoccupation of Sheikh Gumi was combating innovations. His ideas were publicized by his students to the general people. Based on al- 'aqìdah al- șahịhah (the right faith according to the prescriptions of the law), Izalah teachings consist of ideas against the heretical doctrines of Sufi scholars. As it is, the Izalah scholars attempt to show people deviations from the path of the Prophet (S.A.W.) (Loimeier, 1997; Olabiyi, 2002). So, Izalah perceives itself as a protector of the Sunnah, therefore, obliged to fight against anything they consider as an aberration or innovation in Islam. These include any statement or action not mentioned in the Qur' $\bar{\alpha}$ or Sunnah of the Prophet (S.A.W.) or Predecessors. The Izalah scholars' understanding of bid'ah is either major or minor. The major 
ones have to do with faith while the minor ones revolve around mu'ämalāt which includes the likes of naming ceremonies, marriage practices, and social activities of Muslims (Gumi \& Tsiga, 1992; Olabiyi, 2002).

From the linguistic context, the concept of innovation (bid'ah) is complex and dynamic. This establishes the problems of defining the concept, the authority in its definition, how it is understood and the correct usage of the concept. So, Izalah members understood the concept through the guidance of their leaders (Ramzi, 2011). In this, the preachers generalized bid'ah as innovation and as aberration to mean the same thing. However, in mu 'âmalāt, there are certain instances whereby the perception of humans is accepted. The customary practices that do not contradict the Sharī $a h$ (Abu Dawud, Vol.3: 874), are practiced by a large number of people (Ghazzam, n.d), and that are for the benefit of the people are as important as the Sharī'ah rulings themselves.

\section{Relationship between Ib $\bar{\alpha} d a h$ and 'A Adah}

In the same vein, when considering the aspects of worship, bid'ah and 'àd̄̄t are interwoven and stipulated in the Sharī $a h$. Whenever the contrary of bid'ah occurs, it becomes custom or culture (Shāțibī, 1994). Given that a Muslim is considered to be a servant of Allah, even his customary affairs can be categorized as ib $i b d a h$. In Imam Shātibīs' philosophy of bid'ah and 'a $d a h$, he describes ib $\bar{\alpha} d a h$ as whatever the mind cannot comprehend the wisdom behind its stipulations, such as purity, șalōt, șawm and hajj. The rulings are clearly manifested in them as aspects of worship. While anything where the meaning is clear, whether good or bad, like sales, marriage, divorce, and the rest, are customs (Masud, 1995). The Sharì'ah has stipulated a number of conditions for how they can be implemented generally. They can be implemented through a number of ways or choices which follow those conditions. Thus, the two are interlocked in the meaning of $i b \bar{\alpha} d a h$. It follows that when innovation is found in customary acts through this channel, then customs can be accepted as ib $\bar{\alpha} d a h$ (Shāțibī, 1994). Here, there is need to look into legal maxims where custom is accepted as the basis of judgement.

\section{Custom as the basis of judgment." (Al-'Ādah Muhakkamah)}

Legal maxims in relation to the custom and practices of the people begun with the saying of Ibn Mas 'ūd: "'What the Muslims deem to be good is good in the sight of Allah" (Ibn Hanbal). ${ }^{3}$ Several other legal maxims were stipulated by Muslim scholars based on what the Caliph 'Umar (R.A.) wrote to Abū Mūsa al-Ash'arī while serving as a judge (Ahmad, 2014) as well. AlQāọhī Shurayh, during the era of Caliph 'Umar, told the weavers "Follow what is customary among you," based on Al-Bukhōri's report (Mahmassni, 1987). The same applies to some of the legal maxims on customs and practices of the people, such as "People's practice is authority and should be reckoned with" (Isti 'mōl al-nās hujjah yajib al-'amal bi-hī) (Al-Burnu, 1997:306-7). A similar maxim was also recorded by Ḥanafī jurist al-Sarkhasī, and was 
subsequently adopted in the Ottoman Majallah (Mas'ūd, Haydar, Bāz, al-Ghazzi, al-Mahōsini, and al-Atāsi) which provides that 'urf, whether general or specific, is enforceable and constitutes a basis of judicial decisions.

Commonly, the rule must take into consideration the customs and practices of the people in any matter that is not clearly detailed. In other words, custom is not applied where there is a clear text addressing the issue at hand. The same is also applied to the matter whose verdict is based on the customs and practices of the people. The customary practices, which are devoid of benefits and are associated with disadvantages, are not considered as legal 'urf. A custom which does not contravene the principles of Sharīah is valid and authoritative. For example, respect for the mother in-law is in accordance with the text of respect for parents. Apart from being reasonable and acceptable, a custom must be observed and upheld by a court of law (Zakariyah, 2015). In this case, it is what Sharíah considers to be good, not what humans or the prevalent practice considers to be good. Thus, the process of approval prior to acceptance is necessary. Here, the above submaxim has broadened the authority of custom in Islamic law. The Shāfi'ì jurist, al-Suyūtī, in his well-known work, al-Ashbah wa Al-Nazā'ir, recorded a legal maxim which goes as follows; "What is proven by "urf is like that which is proven by a Shar " proof." And "What is known by the virtues of custom is as a stipulated condition" (Al-Suyūtī, 2011).

These two stipulated the conditions binding on people's activities and engagements with others who practice the same custom. This can be effective even though the conditions are not stipulated at that time. For instance, the kayan aure (paraphernal gift) among the Hausa/Fulani custom is considered to be part of the șadaqah. A similar example is cited in the suspension or prompt payment of mahr in marriage, depending on the custom of the area. Thus, it can be a valid marriage if either of the two practices is stipulated based on the custom (Zakariyah, 2015). In fact, the complete area of personal status is one of the crucial sections of law where jurists relied on 'urf consistently.

The importance of 'urf or 'ādah in resolving issues arising in Islamic law is based on consensus of both classical and contemporary Islamic scholars (Zaydan, 1997). There are many ways in which custom is authoritative in Islamic law especially in mu'āmalāt issues, where a specific text is not established (Oba, 2013). Jurists have stipulated some particular instances where the knowledge of customary practices is a necessity, not conditional pre-requisites. These include linguistic conversations, whose interpretation depends on the common customary practices (Oba, 2013), such as oaths, admissions, and divorce utterances. The entire area of personal status is an important section of Islamic law where the jurists consistently relied on custom.

The collection of legal opinions ( fat $\bar{\alpha} w \bar{\alpha})$ are full of references to the common practices on issues ranging from the criteria to determine suitability $\left(k a f \bar{\alpha}^{\prime} a\right)$ in marriage, the amount and manner of payment of dowry, respective contributions of the (would-be) spouses and their 
families, settling marital discords, and the rules governing the process of divorce (Ayman, 2010; Ibn Qudāmah, 1928). The conditions governing the absence of the spouse in terms of estimation in order to deal with issues on inheritance or divorce, the issue of bridal furniture, custody and breastfeeding, and bridal gifts (al-Wansharīsī, 1981). All these and many more are issues on $m u$ 'àmal̄̄t that deal with customary practices, some of which are not the concern of this research. The issue of transactions are part and parcel of the importance attached to 'urf being an authority in Islamic rulings on mu 'àmalāt.

\section{Marriage Customs in Islam}

Custom plays a crucial role in the formulation of family law in Islam. The Qur'ānic injunctions about the family were rectifying pre-Islamic Arab practices. Among the pre-Islamic norms assimilated into Islamic family law include: the Islamic laws on șadāq (mahr), child marriage, social compatibility (kafā'a) (Hafti, 2006), guardianship, (walī) custody, (haḍ̄anah), prohibited relations (muharramōt), verbal repudiation of marriage contract, 'ila, Khul', and delegation of the right of divorce (tafwìl) (Fawzi, 1983). The Sharīah adopts these elements because they reflect reasonability and cultural preferences within a society.

Al-Shătibì mentioned that in the principles of law, all conventional acts are devotional in some way. Any act whose import is not clearly understood as it is intended or prohibited is regarded as a devotional act. For example: ablution, șalāt, șawm are all devotional acts. While those acts, whose imports are obviously understood, their advantage and danger are known, are regarded as conventional acts. Examples of this are marriage, divorce, sales contracts, and criminal offences, as their rulings are clearly understandable. On the other hand, they are restricted by laws as they consist of devotional aspects. This makes the advocate not have the freedom of choice in either dealing with the required or optional acts. Thus, there is a participation in both divisions: devotional acts have conventional and devotional aspects. Thus, an innovation can appear in matters of conventional acts (Al-Shāțibī, 1921).

Therefore, the conventional matters of life have two aspects: one which is progressive and tantamount to change with the passage of time. Islam has no restrictions on this and is not concerned with its compliance or innovations. For example the hadìth states: "You know best the matters pertaining to your worldly affairs" (Al-Bukhari, no. 4358). Here, having good intentions matter; engaging for the pleasure of Allah. Performing any action in such a way makes a Muslim benefit from it and achieve his goals, as his efforts are acts of worship. All customary matters in marriage that do not contradict Islam are based on good intention and piety, clearly explaining the legal maxim- "alumūr bi maqāșidiha" (Matters are determined according to their intentions (Al-Husayn, 2002).

The second part is where boundaries have been drawn by Allah and must be complied with. Islam does not intervene in ordinary conventional matters such as a marriage feast and arrangements so as not to bring hardship upon people. The places where Islam intervenes are 
conventional acts of specific interest which are deemed as divine ordinances, and believed as acts of worship, and portrayed as injunctions from Allah or examples from the life of the Prophet (S.A.W.). For instance, the charity marriage among the Hausa/Fulani Muslims in Gombe is considered by them as an injunction from Allah and a Sunnah of the Prophet (S. A. W. S.), when in reality it is a bid 'ah.

\section{Hausa/Fulani People's Perception on Family}

\section{Customs}

The serious influence of local customs and traditions in Northern Nigeria is one of the reasons behind the $18^{\text {th }}$ century jih $\bar{\alpha} d$ of 'Uthman Dan Fodio. Traces of these uraf survived the jih $\bar{\alpha} d$ (Ibrahim, 2006) and subsequently new ones emerged. The most difficult challenge between custom and Sharī'ah abidance in northern Nigeria is in the area of family regulations. Thus, in northern Nigeria, a mixture of 'ādah and Islam governs the family system (Na'im, 2002). Even though the two are intertwined, customs or traditions overlap with the Sharì'ah of Islam (Kumo, 1988; Ambali, 1998). Some local Muslim scholars have mixed Islam with local traditional practices as a means of commercial livelihood in the name of religion (Yusuf, 1993). To add insult to injury, the colonial authority treated Islamic rulings on family matters as a variant of customary law by modifying its applications (Oba, 2013).

Despite the fact that customs are given a special consideration in Islamic law by incorporating some pre-Islamic Arab-customs into the Islamic mu'āmalāt rulings (Fawzi,
1983), there are some which are frowned at and rejected. Regardless of this interpretation, the scholars among the Hausa/Fulani before the emergence of Izalah did not demarcate between some of the family traditions and the Islamic culture, rather, they considered them to be part of the Sunnah (Hill, 2009). Gombe is not an exception from all the northern states and the people's adherence to their cultures and traditions.

\section{A. 'Urf as Bid'ah in Marriage}

The findings of this research reveal the condition of the people before the emergence of Izalah as that of ignorance of the injunctions and actual teachings of Islam (GMW/AJ/Informant 1, DU9; GMW/SH/Respondent 1, DU3; GMW/PT/Respondent 2, DU3; GMW/JK/Informant 4 , DU3\&7; GMW/NR/Informant 10, DU18). Even though there were Muslim scholars who guided people to authentic teachings of Islam, the method adopted and how regular the exhortation was did not yield much result. Several pieces of literature show the extent of Qādiriyyah and Tijāniyyah teachings in educating Muslims about Islam (Loimeire, 1997; Umar, 1993). Thus, the Izalah movement has publicly declared some aspects of worship among the Sufi brotherhood as bid'ah. At the same time, it has fought against some of the traditions of the Hausa/Fulani. This statement from an Izalah official stands as proof: "Before the teaching and exhorting by the movement, people were wandering in traditions and various kinds of innovations, in all aspects of life" (GMW/ HG/ Respondent 10, DU34). ${ }^{4}$ The aim of the 
organization confirms the Izalah organization's name itself: "elimination of all forms of aberrations or bid'ah (innovations) in Islam." Preaching toward the eradication of bid'ah has led to some practices in the Sunnah (which are not bid' $a h$ ) also to be classified as bid'ah. One of the informants state: "In short, in marriage at least the bid 'ah should be minimized, but instead, new practices are being incorporated" (GMW/AJ/ Informant 1, DU 24). All these statements on bid'ah depend on the understanding of the concept and its utilization.

Among the types of marriage prevalent among the Hausa/Fulani are forced marriages and charity marriages, both of which are contradictory to the injunctions of Islam. In this regard, the scholars have emphasized the protection of public welfare as the primary objective of Islam as far as the consideration of customary matters is concerned (Al-Ghazāli, 1994). Therefore, the Izalah organization carries out clarification about the stand of Islam on all types of marriage.

The result of the interview conducted revealed some misconceptions on the concept of

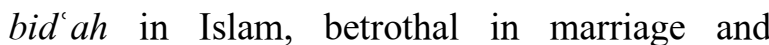
customary wedding celebrations (GMW/SH/Respondent 1, DU3; GMW/AJ/Respondent 8, DU3; GMW/BJ/Informant $\quad 7, \quad$ DU18; GMW/NR/Informant 10, DU26). This comes as a result of the teachings of the Izalah organization to the Muslims there. They categorized the customary practices in weddings as bid'ah instead of 'urf practices. An 'urf where all the stipulated conditions are valid and is observed with good intention, invites the pleasure of Allah. It therefore serves as an act of worship by the servant to his Creator.

The technical definition of bid'ah is: an aberration in Islam, with the intention of acquiring the pleasure of Allah, which resembles Islamic regulations, but has no reason for its validity in the Sharî $a h$. It is initiated with the intention of getting reward from Allah without bases from the Qur' $\bar{\alpha}$ or hadīth.

In Islam worship is divided into two categories: the direct worship between man and his Creator ('ib $\bar{\alpha} d a h)$ and the relationship between human beings (mu' $\bar{\alpha} m a l \bar{\alpha} t)$. In each, regulations and injunctions are stipulated by the law. In marriage for example, the marriage contract itself is an act of worship, which has its prerequisites and conditions. For instance, in the wedding fätihah, stipulations are made based on the conditions for it being valid or invalid (alQurtubī, 2009). These include the wording of offer and acceptance (Ayub, 2002), which should be in accordance with the Islamic injunctions, the șadāq ('Uthman, 1981), witness (Abi al-Zahri, 1947), walī, and the absence of any legal impediments (Oba, 2013; Mahmud, 1981). However, all other activities with respect to the wedding ceremony are left to the customs of the people. Yet, marriage celebration is considered bid 'ah as advocated by the Izalah scholars.

So, going back to the technical definition of bid'ah, it only comes into marriage when new ways of worshipping Allah are designed into the marriage, which have not been mentioned by the Qur' $\bar{\alpha}$ or explicated by the hadīth of the Prophet (S.A.W.). The kind of șadaqa (charity) marriage 
prevalent among the Hausa/Fulani before the inception of the Izalah movement falls in this category. "The sadaqa marriage is another custom within the Hausa/Fulani family" (GMW/JK/Informant 4, DU24). As declared by Abdul-Mumini, they are divided into two. The first type has no basis in Islam ${ }^{5}$, but is intended to serve Allah, as a means of attaining His pleasure and reward. This kind of marriage is bid'ah as the Prophet (S.A.W.) did not mention anything as such. Besides, the regulations and conditions of a valid marriage are not followed. The misconception and misinterpretation of the hadith of the Prophet (S.A.W.) on șadaqatun jōriyatun ${ }^{6}$ (the ongoing charity) makes people seek to obtain the pleasure of Allah in impermissible ways, which leads to the bid'ah in question. Persistent practice and fatwā given by the 'ulam $\bar{\alpha}$ ' then made the nominal Muslims adhere to its regular practice, hence, it became widely accepted as a binding custom among them. Here, the prerequisites of marriage are not accomplished, because it does not recognize the giving of șadāq (dowry) to the bride, and the wedding fattihah (solemnization) is not based on offer and acceptance to a particular husband (At-Tuwaijiry, n.d) and as such, it is null and void. Thus, it falls under the category of invalid customs as it negates the texts on the prerequisites of a valid marriage (Hasiballah, 1976).

The second type is where the sada $q$ (dowry) and other marital gifts are given by the bride's father to the bride in order to help a poor man get married to his daughter. Here, if the person (father) is well known and the wedding fătihah is conducted in his name, and the offer and acceptance are accomplished, it can be considered as helping the poor get married, but there is, as well, no specific text to back such a marriage. The Prophet (S.A.W.) commanded one of his companions to bring șadāq even if it was an iron ring or verses of the Qur' $\bar{\alpha}$ (al-Bukhari, No. 3316). But there is no evidence to show that șada $q$ can be given by the father of the bride in order to assist the poor man to get married. This is a clear-cut bid'ah in marriage which has no basis. Unless if it can be observed from a different perspective where Allah commanded: "And marry the unmarried among you and the righteous among your male slaves and female slaves. If they should be poor, Allah will enrich them from His bounty, and Allah is allEncompassing and all-Knowing" (Al-Nūr: 3).

From this verse, it is clear that Islam encourages marriage and emphasizes its importance. The Muslim ummah is commanded by Allah to engage actively in conducting marriages and supporting each other in this attempt, seeing as celibacy is forbidden (AlKulayni, 1946; Al-Yafi'i, 1994). So, in order to help the poor get married, this verse can be a basis for conducting such marriages, in a different but correct way. As stated by AbdulMunimi that sadaqa marriage is based on the aforementioned verse, which has no basis in Islam (Ambali, 2003). So instead of the incorrect practices of the sadaqa marriage, this verse can be utilized to help the poor get married in a different way: giving donations to them without specifying what the donations are for. The way the donations will be used will be up to the poor person. If a poor man uses it for giving dowry to 
a bride, that is his business. Giving general donations to the poor (who want/need to get married) will be commendable religious acts and the correct utilization of this verse. The outcome of this research suggests something similar to this as the rich should help the poor get married through utilization of the above verse.

One of the achievements of the Izalah organization through their preaching is the minimizing of such kind of bid 'ah marriage. In future situations, the organization can adjust them to suit the Qur'ānic injunctions.

\section{B. 'Urf that is not Bid'ah}

In the marriage contract, all customary practices are allowed as long as they comply with the injunctions of the Qur' $\bar{\alpha}$ and Sunnah. However, the people under study in this research consider any customary act either valid or invalid as bid'ah, based on the preaching of Izalah and the persistent mentioning of bid'ah in almost everything. The absence of demarcation between the concepts of bid'ah and where it can be called as such on the one hand, and the customary practices not in conflict with the injunctions of Islam on the other hand, have contributed towards this misconception. One of the informants declare: “...but still adhered to their urf while, Islam renounces customs." (GMW/KB/Informant 2, DU20). From the above statement, it can be inferred that the informant in question is deficient in awareness of the acceptability of valid customs in Islam. This point in the teachings of the Izalah movement needs to be revisited.
In many audio preaching sessions of Izalah, specifically during its inception, 'urf or 'a dah are categorized as contrary to the tenets of Islam. For instance, in an audio preaching, Isma'ila Idris categorically states: " $A l$ ' $a d a f a b a$ za ta kai ka ko'ina ba," (Tradition or Custom will not lead you into anywhere). However, Islam only denounces customs that contradict its teachings. The majority of the rulings in $m u$ ' $\bar{\alpha} m a l \bar{\alpha} t$ are based on the customary practices where the text did not stipulate any injunction. Such utterances at the inception of the Izalah preaching led to all these misconceptions and so remain as binding. First impressions last longer. Therefore, there is need for Izalah scholars to help clarify such misconceptions and bring out the correct Islamic injunctions in adhering to customary practices.

One of the informants explains the position of the bride's conveyance in Islam where the custom is in accordance with the Sunnah. He declared that: "...there are certain things that are perceived as not allowed, while the religion has permitted them. Example ...women should escort a bride, they think is ...not proper, or women to gather and receive the bride. These are preached against, while it is allowed in Islam" (GMW/PT/Informant 9, DU16). The proof for this is narrated from Aisha (Radiya Allahu anhu) who said: "We accompanied a woman to her wedding with a man of al-Ansār (Madinah residents who accepted Islam and helped the Prophet (S.A.W.)). The Prophet (S.A.W.) said: 'Aisha, won't you have some entertainment? $\mathrm{Al}$ Ansar enjoy entertainment" (Al-Bukhāri, Vol. 7, hadith no. 92). 
In addition to that, there are certain marriage cultural practices that were not rejected by the Prophet (S.A.W.) himself. One of which is that the wedding fätihah should be done publicly and conducted at the masjid. The Prophet (S.A.W.) is reported to have said: "Make known this marriage, perform it in the masjid and celebrate it with the beating of tambourines." (Al-Tirmidhī,)

It was narrated that Abu Husain, whose name was Khalid Al-Madanī, said: "We were in Al-Madinah on the day of 'Ashura and the girls were beating the duff and singing. We entered upon Rubai' bint Mu'awwidh and mentioned that to her. She said: 'The Messenger of Allah entered upon me on the morning of my wedding, and there were two girls with me who were singing and mentioning the qualities of my forefathers who were killed on the day of Badr. One of the things they were saying was: "Among us there is a Prophet who knows what will happen tomorrow." He said: "Do not say this, for no one knows what will happen tomorrow except Allah."”' (Ibn Mājah, no.1897). Another narration said that publicizing of marriage is desirable as the Prophet (S.A.W.) said: "The separator of the lawful and unlawful (in marriage) is the tambourine and the voice." (Ibn Mājah, no. 1896).

Islam permits women to celebrate a wedding by singing tasteful songs, accompanied by a tambourine. Such poems and songs should not promote lust, lewd desire, or portray physical beauty. Instead, they should sing delightful and decent songs to express their happiness with the marriage. Indeed, the duff alone should be used to accompany traditional singing, which should not call to forbidden things or praise that which is forbidden just to announce the wedding and to distinguish the marriage from fornication (Bin Baz, 2001).

Ibn Abbas reported: Aisha (Radiya Allahu anhu) gave away one of her relatives in marriage to a man among the Anșār , and the Messenger of Allah (S.A.W.) came and he said, "Did you send them a girl?" She said: "Yes." The Prophet (S.A.W.) said: "Did you send with her someone to sing?" She said: "No." The Prophet (S.A.W.) said: "Verily, the Anșār are a people who love poetry, so you should send someone along with her to say: Here we come, to you we come, greet us as we greet you" (Ibn Mājah, no.1900). This is a valid custom which the Hausa/Fulani nowadays consider as bid' $a h$.

There is no dispute among Muslim scholars that in a wedding celebration the Prophet (S.A.W.) allowed women to use the duff. The most valid opinion among many scholars is that men can also use drums in order to publicize the marriage thus making it known near and far. The noble Islamic purpose of such publicity is to distinguish between an evil and illicit relationship and a pure and lawful marriage, on the condition that it should not be accompanied by forbidden things, such as undignified singing or music, which excites lust.

It should not lead to fitnah, such as beautiful voices being heard by men and should not cause any annoyance to anyone such as when voices are heard via loudspeakers. The Prophet (S.A.W.) forbade the worshippers in prayer from raising their voices over one another during 
recitation as this causes disturbance and annoyance. Therefore, the voices on loud speakers and the sounds of duff beating can be more disturbing than the worshiping at the masjid (Al-Uthaymin, 2011).

Culture being a natural constitution of any society reflects the physical, mental, and material wellbeing of the people. The moral and cultural values of the people based on ' $\bar{\alpha} d a h$ and 'urf should be preserved to ensure cultural diversity and intergenerational promotion of ethical values. However, the ethical values of the Hausa/Fulani are not the same as before. Several factors can be attributed to this. Denouncing allowable customary practices as bid'ah is one of them. Incorporating unlawful western customs is another. Polishing the existing customary practices to fit with the conditions of valid 'urf is one of the methods that could be utilized by the Izalah movement in order to save the Muslims from discarding allowable customs and from incorporating abhorred western customs into marriages.

\section{Conclusion}

Customary practices are part and parcel of human nature although some require modifications. The activities of the Izalah movement to the Hausa/Fulani Muslims in Gombe is a commendable one. However, some of the existing customary practices are in accordance with the teachings of Islam; they only need to be polished, not condemned as bid'ah. The wisdom is to allow people free choice in terms of customary practices that do not contradict the Qur'ōn and Sunnah, so as not to make life difficult. Choices are given within the boundaries of stipulated conditions based on the Qur' $\bar{\alpha}$ and Sunnah. As a result, customs should be perceived as an integral part of Islamic law if they abide by the rules. Therefore, there is a need for the Izalah organization to double-check and rectify their method of teaching the Qur' $\bar{\alpha}$ and Sunnah of the Prophet (S.A.W.) to the people of Nigeria.

\section{References}

Ahmad, Rashìd. 2014. "Personal knowledge of a judge as a source of proof: An Islamic perspective." Al-Idah 29 Personal knowledge of a judge as a source. Retrieved on 21st October, $2016 \quad$ from www.szic.pk/journal/dec2014/6.pdf.

Ambali, M.A. 1998. The Practice of Muslim Family Law in Nigeria. Zaria: Tamaza Publishing Company.

Ayub, Hassan. 2002. Fiqh al-'Usrah al-Muslimah. Cairo: Dar al-Salam.

Bin Bāz, Abdul Azīz bin Abdullāh. 2001. Fatawa Islamiyah. Riyahd: Darussalam.

Bowen, Glenn. 2009. "Document analysis as a qualitative research method." Qualitative Research Journal 9, no. 2, 27-40.

Bryman, Alan. 2015. Social Research Methods, United Kingdom: Oxford University Press.

Creswell, Williams John. 2013. Research Design: Qualitative, Quantitative and Mixed method Approach, $4^{\text {th }}$ ed., Los Angelis: Sage Publications.

Eniola, Sikiru Gbenga. 2013. “An Islamic Perspective of Sex and Sexuality: A Lesson for Contemporary Muslim," IOSR Journal of Humanities and Social Science (IOSR JHSS) Volume 12, Issue 2. (May. -Jun.): 2028. Retrieved on 13th February, 2017 from www.Iosrjournals. Org.

Farah, Madelain. 1984. Marriage and Sexuality in Islam, A translation of al-Ghazali's book on the Etiquette of marriage from the Ihya. Utah: University of Utah press. 
Haftī, M.R. 2006. Al-'Urf Inda al Usūliyyīn wa Atharuhu fì al-Ahkōm al-Fiqihiyyah. Iskandariyyah: Dōr al-Iman.

Ibrāhìm, Zakyi. 2006. "Islam in Africa: The impact of Dan Fodio's Reforms on the Muslim Family," In Hamdard Islamicus, Vol. XXIX, no.2:69-79.

Ibn Hanbal, Ahmad. 1950. Musnad, Cairo: $\quad$ Dōr al-Ma'arifah.

Ibn Mājah, Muhammad ibn Yazīd. 2000. Sunan Ibn Majah, (Trans,) Muhamad Tufail Ansari. New Delhi: Kitab Bhavan.

Kumo, Suleiman. 1988. "The application of Islamic law in northern Nigeria: Problems and Prospects, "In Islamic law in Nigeria (application \& teachings) edit. Syed KhalidRashid. Kano: Islamic Publication Bureau, Nigeria.

Loimeier, Roman. 1997. Islamic Reform and Political Changes in Northern Nigeria, Illinois: Northwestern University Press.

Keller, Nuh Ha Mim. 1995. The Concept of Bid'a in the Islamic Sharī'ah.Cambridge: Muslim Academic Trust. Retrieved on $11^{\text {th }}$ October 2016 from http://www.masud.co.uk/ISLAnuh/bida.htm

Maḥmud, 'Ābdul Malikk Bappah. 1981. Marriage under Islamic Law. Zaria: Huda-Huda.

Na'im, 'Ābdullahi Ahmad. (ed.). 2002. Islamic Family law in a Changing World: A Global Resource Book. London: Zed Books.

Al-Azahri, Șalih 'Abd al-Samī'. 1947. Zawāhir alIkhalīl: Sharh Mukhtașār al-Islamiyyah, $2^{\text {nd }}$ edit. Cairo: Mușțafāh al-baniy al-habli.

Al-Baghdōd̄̄, A. A. 1999. Al-Talqīn fì al-Fiqh alMōlikī, Beirut: Dōral Kutub alIlmiyyah.

Al-Abaihaqī, Aḥmad ibn Husayn. 2013. Sunan Kubrō, vol.7. Syriah: Dar al Nawadir.

Al-Burnu, Muhammad Siddiq Ahmad. 2002. AlWajīz fì 'ìdāhal Qawā'id al-Fiqhiyyah alKulliyyah, 5th edt. Beirut: Muhassasah alRisālah.

Al-Burnu, Muḥammad Siddiq Ahmad. 1997. Al-Wajīz fì İd̄hal-Qawō'id al Fiqhīyyah alKulliyyah. Riyadh: Maktabah al-Ma'ōrif.
Al-Fayruzabādi, Muhammad ibn Ya'qūb. 1996. Al-

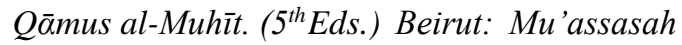
al- Risalah.

Al-Ghazali, Abu Hamid Muhammad. 1994. Majmu'ah Rasa'il al-Imam al Ghazali. Beirut: Dar alKutub al- 'Ilmiah.

Al-Husayn, Ibrāhīm. 2002. Al Qawō'id walDawābițal-Fiqhiyyah li al- Mu'ōmalōt al-Mōliyyha inda Ibn Taymiyyah. Cairo: Dōr al-Ta'șir.

Al-Kulayni, Muhammad ibn Ya'qūb. $1946 . \quad$ AlKōfi. Tehran: Dar al-Kutub al Islamiya.

Al-Nis̄̄'i, Ahmad ibn Shu'aib. 2002. Sunan anNisa'I. Beirut: Dar Al-Fikr.

Al-'Asqal̄̄n̄̄, Abdul Bāqi. 2006. Fath al Bārī Sharh Șahih al-Bukhōrī, Beirut: $\quad$ Dōr al-Kutub al'Ilmiyah.

Al-Isfahōni, al-Husain ibn Muhammad. nd. AlMufradāt fì Gharīb al-Qur'ān. Lebanon: Dār al-Ma'rifah.

Al-Qaradawi, Yusuf. 2013. Lawful and the Prohibited in Islam. Kuala Lumpur: Islamic Book Trust.

Al-Qurtubī, Muhammad ibn Ahmad. 2009. Sharh Bid̄̄yahal- Mujtahīd wa nihōyah alMuqtașid. $\quad 4^{\text {th }} \quad$ edit Cairo: Dōr al-Slam.

Al-Qur'ān, Șaḥiḥ International Translation, https://quran.com.

Al-Qushayrī, Muslim ibn Hajjāj. 1978. Șahih Muslim, (trans.) 'Abdul Hamid Siddiqi Vol. 9. Pakistan: SH. Muhammad Ashraf.

Al-Sajitāniy, Sulayman ibn al-Ash'ath as Sijistāni. 2003. Sunan Abu Dawud. 'Amman: Dar alI'lam.

Al-Suyūțī, Jalāl al-Dìn Abd al-Rahman. 2011. AlAshbah wa al-naza'ir fi qawaid wa furu' al-shāfi' '̄. Cairo: Dōral-sal̄̄m.

Al-Tirmidhī, Muhammad ibn 'Īsá. (n.d.). Al Jōmi' alSahịh. Beirut: Dōr Ihyȳ' al Turōth al- 'Arabī.

At-Tuwaijiry, Muhammad ibn lbrāhìm. The Book of Nikah, Riyadh: Cooperative Office for Call \& Guidance, King Fahd National Library Cataloging in-Publication Data.

Al-Uthaymīn, Muhammad ibn Săliḥ. 2011. Fatawah Islamiyah. Riyadh: Darussalam. 
Al-Wansharīsī, Ahmad ibn Yahyā. 1981. Al Mi yōrwa

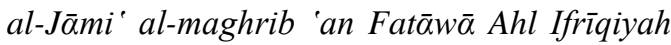
wa al-Andalus wa al-maghrib. Rabat:

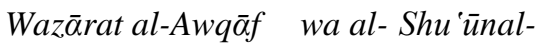
Islōmiyyah.

Al-Yafi'i, Abdallah ibn Sa 'ad. 1994. Al Targhīb wa Al Tarhīb. Tanta: Dōral Sahōba lil alTurōth.

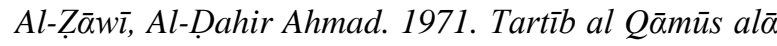
Darīq al-Miṣbōh al Mun̄̄r Wa As̄̄s alBal̄̄gh. $\quad 3^{\text {rd }}$ edn. Libya: $\bar{I} s \bar{\alpha}$ alAbōniy al Halib \& Co.

Al-Zarqa, Musțafah Ahmad. 1983. Al Madkhal al Fiqhīal-'Āmm. Damascus: Matba'ah Jami'ah.

Fawzi, Ibrahīm. 1983. Ahkōm al-Usrah fì alJahilīyah wa-al-Islam. Beirut: Dōr kalimāt lil Nashri.

Gumi, Abubakar. \& Tsiga, Ibrahim. 1992. Where I stand. Ibadan: Spectrum books.

Hasiballah, 'Ali. 1976. 'Usul al-Tashrī il-Islāmī. Cairo: Dōr al-Ma'rifah.

Hill, Margari. 2009. "The spread of Islam in West Africa: containment, mixing, and reform from the eighth to the twentieth century." SPICE digest.

Ibn 'Ābidīn, Muhammad Amin. 2000. Hāshiyah, ibn 'Ābidīn or Radd al Muḥtār 'Alā al-Durar alMukhtār. Beirut: Dāral-Fikr.

Ibn Hanbal, Aḥmad. 1950. Musnad, Cairo: $\quad$ Dōr al-Ma'arifah.

Ibn Qudōmah, Muhammad ibn Abdallah ibn Ahmad. 1982. Al-Mughnī. Cairo: Matba'at alManar.

Ibn Manzūr, Muhammad ibn Mukarram. 1990/1410. Lisān al 'Arab. $1^{\text {st }}$ ed. Beirut: Dār Șādir.

Ibn Taymiyyah, Taqī ad-Dīn Aḥmad. 2001. AlQawā'id al- Nūrāniyyahal Fiqhiyyah, Riyadh: Maktabatal Rushd.

Idris, Isma'îl. 1986. Kira ga Musulunci, Audio Cassette: $1^{\text {st }}$ January. Alkaleri: Nigeria.

Kamāli, Muhammad Hāshim. 2003. Principles of Islamic Jurisprudence. $3 r d$ Edit. United Kingdom: The Islamic Texts Society.
Loimeier, Roman. 1997. Islamic Reform and Political Change in Northern Nigeria. Evanston: Northwestern University Press.

Mahmassni, Sobhi. 1987. Falsafat al Tashri' fi Islam, Farhat J. Ziadeh, (trans.) The Philosophy of Jurisprudence in Islam. Malaysia: Penerbitan Kizbi.

Mahmud, Abdul-Malik Bappah. 1981. Marriage under Islamic Law. Zaria: Huda-Huda.

Masud, Muhammad Khālid. 1995. Shōṭibī's Philosophy ofIslamic Law. Kuala Lumpur: Islamic Book Trust.

Modibbo, Muhammad. 2012. "Survey of Muslim groups in Plateau state of Nigeria." NRN Background Paper 4.

Oba, Abdal-Mu'min. 2013. "Judicial Practice in Islamic Family law and its relation to 'Urf (Custom) in northern Nigeria”, In Islamic Law and Society, Vol.20, no.3: 272318.

Olabiyi, Adekunle. 2002. "Izōlatul-Bid'ah Movement in Nigeria (1973-2003)," Ph.D. thesis, University of Ibadan.

Ousman, Kane .2003. Muslim Modernity in Postcolonial Nigeria. Boston: Brill. Quirk, Randolph et al (eds). 1987.

Dictionary of Contemporary English. Essex: Longman Group U.K. Limited.

Ramzi, Ben Amara. 2011. "The Izala Movement in Nigeria: Its Split, Relationship to Sufis and Perception of Sharīah Re Implementation," (PhD. Thesis) Bayreuth: International graduate school of African studies.

Salisu, Taiwo Mashood. 2013. "'Urfl'Adah (custom): An Ancillary Mechanism in Sharīah”, Ilorin Journal of Religious Studies, (IJOURELS), Vol.3.No.2: 133-148.

Shatibi, Ibrāhīm ibn Mūsā. 1994. Al I'tisam. Cairo: Dōr Al-Kutubal-Khadiwiyyah.

Shatibi, Ibrāhīm ibn Mūsā. 1921. Muwāfaqāt fì 'Ușūl al Ahkōm. Cairo: Maṭba'ah al-Ṣalafìyyah.

Shoboyede, T. O. 1992. "Religion and culture," in The Truth, Vol. xxx, No.2.

Șiddiqi, Abdu al-Hamīd. 1976. (Trans.) Șaḥị̣ Muslim. Lahore: SH.Muhammad Ashraf. 
Thurston, Alexandra. 2009. Interactions between Northern Nigeria and the Arab World in the Twentieth Century.

Uthman, A. 1981. 'Āthar uqdah al Zawaj fi alshari'ah al-Islamiyah. Riyadh: Imam Muhammad bin Saud Islamic University.

Yusuf, Balkisu. 1993. "Da'wah and ContemporaryChallenges Facing Muslim Women in Secular States: A Nigerian Case study" In Islam in Africa, A proceedings of the Islam in Africaconference. (Ed) Nura Alkali, Adamu Adamu, Awwal Yadudu, Rashid Motem \& Haruna Salihi. Ibadan: Spectrum Books limited.

Zakariyah, Luqman. 2015. Legal Maxims in Islamic Criminal Law: Theory and Application Boston: Brill.

Zakariyah, Luqman. 2012. "Custom and Society in Islamic Criminal Law: A Critical Appraisal of the Maxim 'al- 'Ādah Muhakkamah' (Custom is Authoritative) and it's Sisters inIslamic Legal Procedures," ArabLaw Quarterly 26: 75-97.

Zaydan, Abd al-Karīm. 1405/1985. Al Madkhal liDirāsat al-Sharī ah al Islāmiyah. $9^{\text {th }}$ Edit. Beirut: Al- Risālat Publishing.

\section{Endnotes}

i This paper is part of the $\mathrm{Ph}$. D. thesis submitted to the International Islamic University Malaysia.

2 Throughout this paper, the word Izalah is utilized.

3 This hadith does not go back to the Prophet (S. A. W. S.), it stops with Ibn Mas'ūd and most of the scholars attribute it to his sayings, not to the Prophet.

${ }^{4}$ Several such statements and the like are found in the various lectures delivered by the Izalah scholars especially during the inception of the organization.

${ }^{5}$ It is the type where the wedding fatihah is concluded with the name of Muhammad (S. A. W. S.) and the bride may end-up with Ibrahim for example.

6 This is misinterpretation of the Prophetic hadith which talks about the three lasting good deeds of a man after his death. Abu Hurayrah reported: The Messenger of Allah, (S. A. W. S.) said: "When the human being dies, his deeds come to an end except for three: ongoing charity, beneficial knowledge, or a righteous child who prays for him." (Muslim: 1631). The "ongoing charity" mentioned in the hadith, is good deed whereby people will continue to benefit from its fruits, like building of schools, hospitals,
Masājid, sources of drinking water and so on. But it is translated as 'charity of a young lady' instead of the actual meaning of the hadith. The actual Arabic word of this segment is: 'Sadaqah Jōriyah' and it's pronunciation as: 'Sadakati al-Jariya' causes the distortion of its context. 